\title{
PLASMALOGENS IN THE GILL LIPIDS OF AQUATIC ANIMALS
}

\author{
J. C. Nevenzel, A. Gibbs and A. A. Benson \\ Scripps Institution of Oceanography, A-002, La Jolla, CA 92093, USA
}

(Received 12 March 1985)

\begin{abstract}
Lipids constituted $0.6-2.2 \%$ wet wt of the gills of 11 species of aquatic animals ( 4 bivalves, a crustacean and 6 fishes).

2. Phospholipids, largely phosphatidylcholine (PC) and phosphatidylethanolamine (PE), are major components of all species.

3. The plasmalogen contents of these lipids were $47-291 \mu \mathrm{mol} / \mathrm{g}$, with the highest values found for bivalve gill total lipids and the catfish phospholipid fraction.
\end{abstract}

\section{INTRODUCTION}

Preliminary to a study of the effect of lowered $\mathrm{pH}$ on the gills of aquatic animals we analyzed the gill lipids of 11 species for their content of plasmalogens, 1-(1'-alkenyl)-2-acyl-phospho-glycerides [and any 1-(1'-alkenyl)-2,3-diacyl-glycerols].

The plasmalogen content of gills has previously been determined quantitatively only for an Octopus sp. (Dembitskii, 1981) and the trout, Salmo trutta (Bolis et al., 1984). Dumont (1958) found a "high" plasmalogen level in the posterior gill of Eriocheir sinensis and Rapport (1961) reported that the highest plasmalogen levels in both an unspecified bivalve and a Loligo sp. were in gill tissues. Total lipid contents, phospholipid fraction, the phospholipid classes present and their fatty acid compositions in gills of aquatic animals have been investigated in several laboratories; specific papers are cited below in Results and Discussion.

Vaskovsky, Dembitskii and colleagues in the USSR have published extensive data on the plasmalogens of the total body lipids of over 60 marine species from sponges to tunicates (Dembitskii and Vaskovsky, 1976; Dembitskii et al., 1977; Dembitskii, 1979, 1980, 1981; Kostetsky and Gerasimenko, 1984). Other investigations published since the reviews in Snyder's (1972) book Ether Lipids report the plasmalogens in coral (Parker et al., 1984); molluscs, including abalone (de Koning, 1966; Joh and Hata, 1979), a top shell (Joh and Hata, 1979) and bivalves (Sampugna et al., 1972; Joh and Hata, 1979; Chelomin and Zhukova, 1981); and in a tunicate (Hayashi et al., 1979). Plasmalogen analyses of fish tissue other than gills are: brain (Selivonchick and Roots, 1976; Driedzic et al., 1976; Kruglova, 1979), muscle mitochondria (Wodtke, 1981), optic nerve (Matheson et al., 1981) and erythrocyte membranes (Nelson, 1972; 1979; Warren et al., 1979).

\section{MATERIALS AND METHODS}

The catfish was purchased from Aquatic Systems Incorporated, La Jolla, CA; the crayfish and freshwater mussels from College Biological Supply Co., Escondido, CA; the trout and beef heart (as a reference standard) from Mayfair Markets, La Jolla, CA. The rock scallops were cultured in the Bivalve Mariculture Laboratory, S10; the oysters were purchased on the Atlantic Coast of Florida and maintained in running local seawater. The mussels, leopard shark and keip bass were collected off Scripps; the tuna was caught on hook and line off San Diego; and the sturgeon netted in the Sacramento River Delta, California.

The freshwater mussels and crayfish were maintained under the irregular light regimen of the working laboratory in aerated tap water, changed every second day. The crayfish were fed canned fish or a pelleted pet food twice a week, and the clams received yeast once a week. The gills were dissected out and extracted with chloroform-methanol by the Bligh and Dyer (1959) technique, using either the whole gills (invertebrates and tuna) or the soft tissue (mucosa) scraped from the filaments (remaining fish species). The solvent was evaporated under nitrogen with slight warming to obtain the total lipids. For some species this was further fractionated into neutral, glyco- and phospholipid by column chromatography on silicic acid (Bio-Rad A, Bio-Rad Laboratories, Richmond, CA), eluting the neutral lipids with 4 column volumes $(=4 \mathrm{vol}$.) of chloroform, "glycolipids" with 5 vol. of acetone and the phospholipids with 3 vol. of methanol (Patton and Thomas, 1971).

Total 1'-alkenyl (vinyl) ethers were determined by the iodine-uptake method of Williams et al. (1962), simplified. Aliquots of $50-800 \mu \mathrm{g}$ of lipid were dissolved in $0.9 \mathrm{ml}$ of methanol with shaking and warming as necessary for complete solution. Buffer $(3.2 \mathrm{ml}$ of $0.094 \mathrm{M}$ citrate of $\mathrm{pH} 5.5)$, $0.85 \mathrm{ml}$ of $3 \mathrm{~m} \mathrm{KI}$, and $50 \mu 1$ of $5 \mathrm{mM} \mathrm{I}_{2}$-in-3-M-KI were added. After $40 \mathrm{~m}$ at room temperature the absorbance at $363 \mathrm{~nm}$ was measured in a Beckman DU Spectrophotometer (Beckman Instruments, South Pasadena, CA) fitted with a Gilford Photometric Accessory (Gilford Instrument Laboratories, Inc., Oberlin, $\mathrm{OH}$ ). Two blanks were run: (a) omitting lipids and (b) with $0.9 \mathrm{ml} 3 \mathrm{M} \mathrm{KI}$ but no iodine. Our simplification consisted in measuring the absorbance of the reaction mixture directly, rather than that of an $N$-butyl acetate extract. The net iodine uptake was calculated assuming for $\mathrm{KI}_{3}$ at $363 \mathrm{~nm}$ a molar extinction $(1 \mathrm{~cm})$ of $2.12 \times 10^{4}$ (Williams et al., 1962). The weight of plasmalogen was estimated assuming (a) a ratio of PEplasmalogen to PC-plasmalogen of 2, (b) an 18:1 alkenyl ether chain (cf. Bell et al., 1983) and (c) an acyl moiety of the average molecular weight found for the polyunsaturated acids of the three gill phospholipids we analyzed (Table 1) 
Table 1. Fatty acids of gill lipids

\begin{tabular}{ccccc}
\hline & $\begin{array}{c}\text { Crayfish } \\
\text { PL }\end{array}$ & $\begin{array}{c}\text { Catfish } \\
\text { PL* }\end{array}$ & NL ${ }^{*}$ & PL \\
\cline { 3 - 5 } $14: 0$ & & 0.27 & $<2.86$ & \\
$16: 0$ & 0.98 & 9.98 & 18.67 & 6.18 \\
$16: 1$ & 2.21 & 1.28 & 2.96 & 0.44 \\
$17: 0$ & 0.61 & 1.16 & $\simeq 0.58$ & 0.72 \\
$17: 1$ & 1.09 & & 1.19 & 1.73 \\
$18: 0$ & 15.34 & 16.19 & 7.48 & 31.72 \\
$18: 1$ & 24.50 & 14.79 & 24.35 & 6.94 \\
$18: 2$ & 5.57 & 5.29 & & 0.60 \\
$18: 3$ & 1.23 & 0.05 & & nd \\
$20: 0$ & 0.75 & & & 1.36 \\
$20: 1$ & 3.97 & 1.03 & 3.11 & 2.67 \\
$20: 2$ & 2.32 & & & \\
$20: 4$ & 11.43 & 13.63 & 8.42 & 9.72 \\
$20: 5$ & 15.32 & 2.56 & & 7.49 \\
$22: 1$ & & & $<1.22$ & \\
$22: 5$ & 0.90 & 1.05 & & 2.74 \\
$22: 6$ & 2.00 & 10.24 & 24.30 & 26.02 \\
\hline
\end{tabular}

$\mathrm{NL}=$ neutral lipid, $\mathrm{PL}=$ phospholipid, $\mathrm{nd}=$ not detected.

*Acid-catalyzed methanolysis. Five unidentified components of ECL N.48 \pm 0.03 on OV-1 (14.48-21.46) totalling $12.68 \%$, and two (ECLs 18.17, 19.29) totalling $8.17 \%$ may be dimethyl acetals (or derived products). On SP-2300/2310 they seem to coincide with the $\mathrm{C}_{15}-\mathrm{C}_{18}$ monoenes.

+GLC on OV-1 only; mono-, di- and trienes eluted as one component

namely 294 (this corresponds to a $C_{20.5}$-chain with 4.5 double bonds), giving a plasmalogen average molecular weight of 770 .

A component of the tuna gill lipids absorbed at $363 \mathrm{~nm}$, giving a high background in the $\mathrm{I}_{2}$-uptake technique. Measuring absorbance in the $N$-butyl acetate phase following extraction - the original procedure-gave acceptable results. However, we also tried a version of the phenylhydrazine technique used for marine invertebrates by Rapport and Alonzo (1960), attempting to adapt Katz and Keeney's (1966) dinitrophenylhydrazine method to the micromolar scale. Analyses of tuna gill and beef heart total lipids using the original $66 \mathrm{mM}$ reagent gave generally higher values than obtained by $\mathrm{I}_{2}$-uptake. When the reagent was diluted 100 -fold the background measured was very high, probably because of carbonyl compounds present, or formed on standing, in the alcoholic reagent solution; we worked under normal laboratory illumination, disregarding possible photochemical reactions mentioned by Dittmer and Wells (1969).

We examined most of the gill lipids by two-dimensional thin-layer chromatography (TLC) on precoated plates (Silica Gel 60, EM Science, Cincinnati, $\mathrm{OH}$ ) developed with the solvents of Parsons and Patton (1967), and using the Dittmer and Lester (1964) spray or Phospray (Supelco, Inc., Bellefonte, PA) to locate the spots containing organic phosphorous. Attempts to establish the presence of plasmalogen components of PE and PC by the technique of Dembitskii and Vaskovsky (1976) by exposing the TLC plate to $\mathrm{HCl}$ between the first and second developments (cf. Horrocks, 1968) gave erratic results. The oyster and crayfish total lipids were quantitated after chromatographic separation on S-I Chromarods in the Iatroscan (Model TH-10 TLC Analyser MK II, Newman-Howells Associated Limited, Winchester, UK; cf. Ackman, 1980).

Gas-liquid chromatography (GLC) was done with the fatty acid methyl esters prepared from the lipid fractions by either (a) reaction at $80^{\circ} \mathrm{C}$ for $3 \mathrm{~min}$ with sodium methoxide in methanol (Blanquet et al., 1979) or (b) $1 \mathrm{hr}$ heating at $80-85^{\circ} \mathrm{C}$ in benzene plus $3 \mathrm{M}$ methanolic $\mathrm{HCl}$ (Supelco, Inc.) in a vial with a Teflon cap. In the latter procedure the reaction mixture was cooled, neutralized with powdered $\mathrm{NaHCO}_{3}$, and partitioned between water and benzene. The aqueous phase was washed twice with benzene and the combined benzene phases evaporated carefully under nitrogen with warming. The acid-catalyzed transmethylation leads to methyl esters plus the dimethylacetals from the 1-alkenyl chains of the plasmalogens; the base-catalyzed reaction gives only the methyl esters (plus non-volatile l-alkenyl glyceryl ethers). We had difficulty interpreting the GLC results from the acid-catalyzed preparations in the absence of dimethyl acetal standards and in view of the lability of these products during GLC on metal columns (Stein and Slawson, 1966). Most analyses were done on a $1.83 \mathrm{~m} \times 3.18 \mathrm{~mm}$ ID stainless steel column of $\mathrm{OV}-1$ on 100/120 GasChrom Q (Applied Science Laboratories, State College, PA) or a $2.0 \mathrm{~m} \times 2.0 \mathrm{~mm}$ ID glass column of $2 \%$ SP-2300 $+3 \%$ SP-2310 on $100 / 120$ Chromosorb WAW (Supelco, Inc.) in the Hewlett-Packard Model 5840A Gas Chromatograph (Hewlett-Packard Co., Palo Alto, CA).

\section{RESULTS AND DISCUSSION}

From our values (Table 2) bivalve and crustacean gills seem to have less lipid $(0.38-0.78 \%$ wet wt or $15.5 \%$ dry wt) than do teleost gills $(0.98-2.2 \%$ wet wt). However, this difference is not confirmed by published values: bivalves $26.6 \%$ dry wt (Klingensmith and Stillway, 1982); crustaceans $0.85-3.63 \%$ wet wt (Dumont, 1958; Giese, 1966; Chapelle et al., 1976; Chapelle, 1977), 11.7\% dry wt (Shinonura et al., 1983); and teleosts $1-3.06 \%$ wet wt (Thomas and Patton, 1972; Zwingelstein et al., 1973, 1980) or 21-34\% dry wt (Lizenko et al., 1975). In three marine invertebrates the gill phospholipids constitute $75 \pm 18 \%$ of the total lipid (Klingensmith and Stillway, 1982; Chapelle et al., 1976; Chapelle, 1977), considerably higher than our fresh water crayfish gravimetric value of $25 \%$ (Table 2). The Iatroscan crayfish values are in good agreement if we assume that on the chromarods the glyco- and phospholipids appear as a single zone. Teleost gill phospholipids are ca $54 \%$ in Anguilla anguilla (Zwingelstein et al., 1980) or $60-76 \%$ in nine marine species (Thomas and Patton, 1972), all considerably higher than our $36 \pm 2 \%$ for two marine species.

Dumont (1958) found a high content of plasmalogens in the posterior gill of Eriocheir sinensis, while Rapport (1961) reported that the highest plasmalogen contents in both a bivalve and a squid were in their gill tissues, being over $400 \mu \mathrm{mol} / \mathrm{g}$ in the bivalve; compare our $264 \pm 17 \mu \mathrm{mol} / \mathrm{g}$ for four species of bivalves-the highest values in Table 2 except for the catfish gill phospholipids. The Octopus sp. gills investigated by Dembitskii (1981) contained $13.7 \%$ of the total lipid phosphorous as PE and phosphatidylserine (PS) plasmalogens, while the PE and PC plasmalogens in trout gills totaled $30.7 \%$ (Bolis et al., 1984). In our hands the iodine-uptake method when applied to beef heart gave results (plasmalogens $25.7 \mathrm{wt} \%$ of total phospholipids) in agreement with Dawson et al.'s (1962) maximum plasmalogen value of $28.5 \mathrm{~mol} \%$ of total lipid phosphorous. The 1-alkenyl ethers are expected to be major components only of the phospholipids, as in our catfish analyses (Table 2), so the kelp bass data are apparently anomalous in having a higher vinyl ether content in neutral lipids than in phospholipids (115 vs $48 \mu \mathrm{mol} / \mathrm{g}$ ), although "neutral plasmalogens" [i.e. 1-(1'-alkenyl)-2,3-diacylglycerols] are well known in aquatic animals (cf. Snyder, 1970, 1972). 


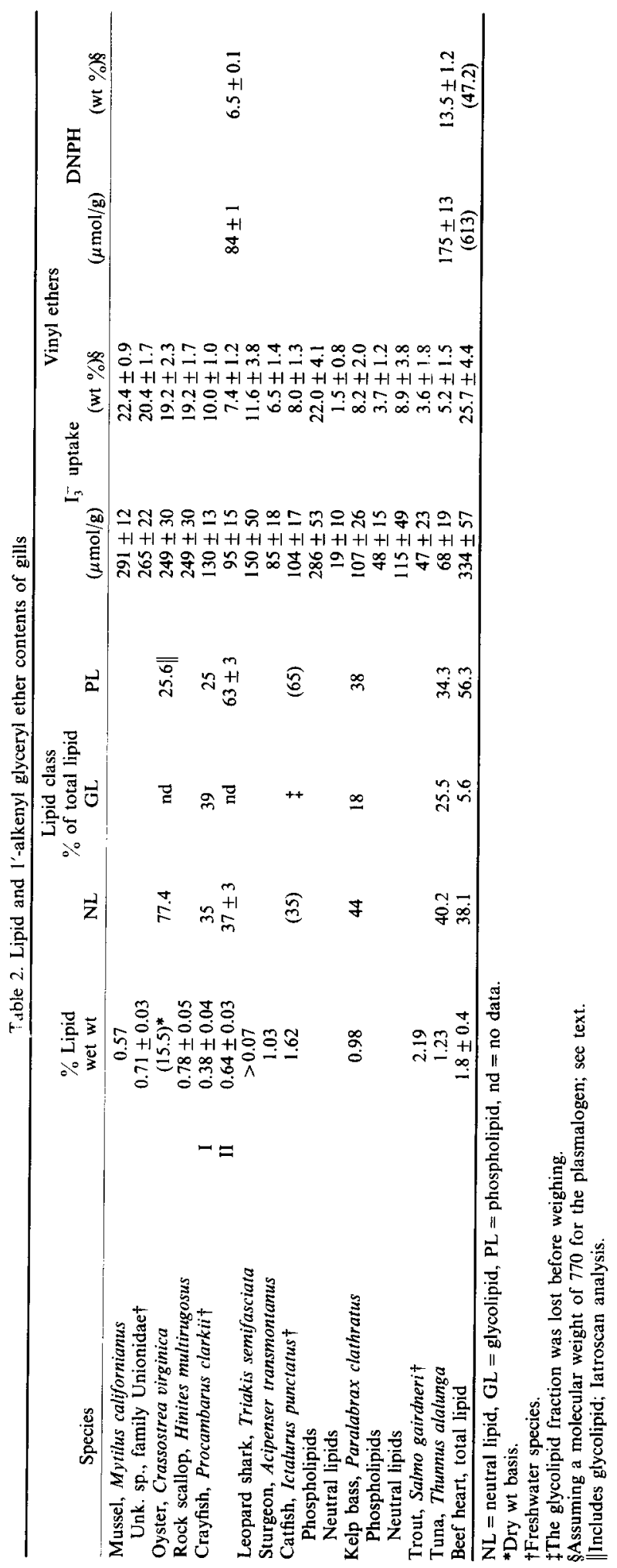


Cursory examination by TLC showed PC and PE to be the main components of the phospholipids of catfish, tuna and kelp bass; Thomas and Patton (1972) found $62.3 \% \mathrm{PC}$ and $17.6 \% \mathrm{PE}$ in kelp bass gills. Semiquantitative analyses using the Iatroscan (Ackman, 1980) confirmed these observations for crayfish gills (PC $64 \pm 4 \%$ of total phospholipids, PE $23 \pm 3 \%$ ) and oyster gills (PC 61\%, PE 39\%). These values are high since minor components were not quantified, but the ratios of $\mathrm{PC} / \mathrm{PE}$ found, 1.56-3.35, are commensurate with the literature range of 1.80-2.50 for total gill lipids in three species of marine crustaceans (Chapelle et al., 1976, 1982b; Chapelle, 1977); in the gill mitochondria this ratio tends to be lower: 1.27-2.20 (Chapelle et al., 1981, 1982a). The gill of Dembitskii's (1981) Octopus sp. contained less $\mathrm{PC}$ than $\mathrm{PE}$ for a ratio of 0.733 . In teleost gills the published $\mathrm{PC} / \mathrm{PE}$ ratios are: fresh water species, trout 2.06 (Bolis et al., 1984), goldfish gill mitochondria 1.55-2.04 (Anderson, 1970; Caldwell and Vernberg, 1970); nine species of marine fish $2.77 \pm 0.59$, range 1.93-3.61 (Thomas and Patton, 1972; Zwingelstein et al., 1973, 1975). A mesopelagic marine species with a low PE content had PC/PE of 12.95 (Thomas and Patton, 1972). Environmental temperature (Anderson, 1970; Caldwell and Vernberg, 1970; Chapelle et al., 1981; Hazel, 1984), acidity (Bolis et al., 1984), or salinity (Chapelle et al., 1976, 1982a) affect this ratio.

The fatty acid analyses of Table 1 are representative of other gill data, with a high content of polyunsaturated $\mathrm{C}_{20}$ and $\mathrm{C}_{22}$ components $(27-46 \%$ ) and a comparatively high level of 18:0 (15-32\%) in phospholipids. The tuna gill neutral lipids still have high polyunsaturated fatty acids $(33 \%)$, the highest $16: 0$ content $(19 \%)$ but lower 18:0 (7\%).

Acknowledgements - This work was supported through the Ecological Research Division, Office of Health and Environmental Research, Department of Energy. We thank Dr. Michael E. Newman for initial exploratory experiments and in particular for help in maintaining the crayfish in the laboratory. The following provided animals: Elizabeth Pelz; S. Craig Cary, Bivalve Mariculture Laboratory, SIO Scripps Aquarium; Dr. Serge I. Dorshov, UCD, and Devon Bartley, Hubbs Sea World, San Diego, CA. J. L. Hakanson made the Iatroscan analyses.

\section{REFERENCES}

Ackman R. G. (1980) Flame ionization detection applied to thin-layer chromatography on coated quartz rods. Meth. Enzymol. 72, 205-252.

Anderson T. R. (1970) Temperature adaptation and the phospholipids of membranes in goldfish (Carassius auratus). Comp. Biochem. Physiol. 33, 663-687.

Bell M. V., Simpson C. M. F. and Sargent J. R. (1983) $(n-3)$ and $(n-6)$ polyunsaturated fatty acids in the phosphoglycerides of salt-secreting epithelia from two marine fish species. Lipids 18, 720-726.

Blanquet R. S., Nevenzel J. C. and Benson A. A. (1979) Acetate incorporation into the lipids of the anemone Anthopleura elegantissima and its associated zooxanthellac. Mar. Biol., Berlin 54, 185-194.

Bligh E. J. and Dyer W. J. (1959) A rapid method of total lipid extraction and purification. Can. J. Biochem. Physiol. 37, 911-917.

Bolis C. L., Cambria A. and Fama A. (1984) Effects of acid stress on fish gills. In Toxins, Drugs, and Pollutants in Marine Animals (Edited by Bolis C. L. and Gilles R.), pp. 122-129. Springer Verlag, Berlin.

Caldwell R. S. and Vernberg F. J. (1970) The influence of acclimation temperature on the lipid composition of fish gill mitochondria. Comp. Biochem. Physiol. 34, 179-191.

Chapelle S. (1977) Lipid composition of tissues of marine crustaceans. Biochem. Syst. Ecol. 5, 241-248.

Chapelle S., Dandrifosse G. and Zwingelstein G. (1976) Metabolism of phospholipids of anterior or posterior gills of the crab Eriocheir sinensis M. Edw., during the adaptation of this animal to media of various salinities. Int. $J$. Biochem. 7, 343-357.

Chapelle S., Brichon G. and Zwingelstein G. (1981) Effect of environmental temperature on the phospholipid metabolism of gill mitochondria of Carcinus maenas. Biochem. Syst. Ecol. 9, 333-338.

Chapelle S., Chantraine J. M. and Pequeux A. (1982a) Gill phospholipids of mitochondria in euryhaline crustaceans as related to changes in environmental salinity. Biochem. Syst. Ecol. 10, 65-70.

Chapelle S., Dandrifosse G. and Zwingelstein G. (1982b) Incorporation of $\left({ }^{3} \mathrm{H}\right)$ oleic acid into phospholipids of the crab Maja squinado. Wasman J. Biol. 40, 90-97.

Chelomin V. P. and Zhukova N. V. (1981) Lipid composition and some aspects of aminophospholipid organization in erythrocyte membrane of the marine bivalve mollusc Scapharca broughtoni (Schrenk). Comp. Biochem. Physiol. 69B, 599-604.

Dawson R. M. C., Hemington N. and Davenport J. B. (1962) Improvements in the method of determining individual phospholipids in a complex mixture by successive chemical hydrolyses. Biochem. J. 84, 497-501.

Dembitskii V. M. (1979) Plasmalogens in phospholipids of marine invertebrates. Biol. Morya, Vladivostok 1979, No. 5, 86-90.

Dembitskii V. M. (1980) Lipids of marine origin. A study in Ophiura sarsi phospholipids. Bioorg. Khim. 6, 426-430

Dembitskii V. M. (1981) Plasmalogen contents of phospholipid classes of various organs and tissues of Octopus sp. Zh. Evol. Biokhim. Fiziol. 17, 296-298.

Dembitskii V. M. and Vaskovsky V. E. (1976) A quantitative distribution of plasmalogens in different phospholipid classes of marine invertebrates. Biol. Morya, Vladivostok, No. 5, 68-72.

Dembitskii V. M., Svetashev V. I. and Vaskovsky V. E. (1977) Lipids of marine origin. I. Unusual lipid from the phospholipids -including plasmalogens-- of Halichondria panicea. Bioorg. Khim. 3, 930-933.

Dittmer J. C. and Lester R. L. (1964) A simple, specific spray for the detection of phospholipids on thin-layer chromatograms. J. Lipid Res. 5, 126-127.

Dittmer J. C. and Wells M. A. (1969) Quantitative and qualitative analyses of lipid and lipid components. Meth. Enzymol. 14, 494-496.

Driedzic W., Selivonchick D. P. and Roots B. I. (1976) Alk-l-enyl ether-containing lipids of goldfish (Carassius auratus L.) brain and temperature acclimation. Comp. Biochem. Physiol. 53B, 311-314.

Dumont P. (1958) Présence d'un acétalphosphatide dans le branchiés du crabe Ériocheir sinensis (M. Edw.) en relation avec le méchanisme de transport actif de ion minéraux. Archs int. Physiol. Biochim. 66, 373-385.

Giese A. C. (1966) Lipids in the economy of marine invertebrates. Physiol. Rev. 46, 259-264.

Hayashi A., Morita M. and Matsura F. (1979) Analysis and quantitation of molecular species of phospholipids from sea squirts, including ether analogutes. Paper No. 179. $J$. Am. Oil Chem. Soc. 56, 197A.

Hazel J. R. (1984) Effects of temperature on the structure and metabolism of cell membranes in fish. Am J. Physiol. 246, R460-470.

Horrocks L. A. (1968) The alk-1-enyl group content of 
mammalian myelin phosphoglycerides by quantitative two-dimensional thin-layer chromatography. J. Lipid Res. 9, 469-472.

Joh Y. and Hata M. (1979) Studies on the lipids of abalone. II. The aldehyde composition of plasmalogen from abalone and some marine molluscs. Han'guk Susan Hakhoe Chi 12, 181-189; (1980) Chem. Abstr. 93,92070u.

Katz I. and Keeney M. (1966) Quantitative micro determination and isolation of plasmalogen aldehydes as 2,4-dinitrophenylhydrazones. J. Lipid Res. 7, 170-174.

Klingensmith J. S. and Stillway L. W. (1982) Lipid composition of selected tissues of the hardshell clam, Mercenaria mercenaria. Comp. Biochem. Physiol. 71B, 111-112.

Koning A. J. de (1966) Phospholipids of marine origin. IV. The abalone (Haliotis midae). J. sci. Food Agr. 17, 460-464; (1966) Chem. Abstr. 65, $19042 \mathrm{e}$.

Kostetsky E. Y. and Gerasimenko N. I. (1984) Phospholipid composition and phylogeny of echinoderms. Biol. Morya, Vladivostok 1984, No. 1, 39-46.

Kruglova E. E. (1979) Studies on fatty aldehydes of plasmalogen form of ethanolamine phospholipid in the brain of vertebrates. Zh. Evol. Biokhim. Fiziol. 15, 339 346.

Lizenko Y. I., Siderov V. S. and Potapova O. I. (1975) Seasonal variations in the lipid composition of the tissues and organs of the large cisco (Coregonus albula) in Karelian lakes. Voprosy Ikthiol. 15, 519-529; J. Ichthy. 15, 465-472.

Matheson D. F., Oei R. and Roots B. I. (1981) Changes in fatty acyl composition of phospholipids in the optic tectum and optic nerve of temperature acclimated goldfish. Physiol. Zool. 53, 57-69.

Nelson G. J. (1972) Lipid composition and metabolism of erythrocytes. In Blood Lipids and Lipoproteins; Quantification, Composition and Metabolism (Edited by Nelson G. J.), p. 336. Wiley, New York.

Parker J. H., Nickels J. S., Martz R. F., Gehron M. J., Richards N. L. and White D. C. (1984) Effects of welldrilling fluids on the physiological status and microbial infection of the reef building coral Monastrea annularis. Archs envir. Contam. Toxicol. 13, 113-118.

Parsons J. G. and Patton S. (1967) Two-dimensional thinlayer chromatography of polar lipids from milk and mammary tissue. J. Lipid Res. 8, 696-698.

Patton S. and Thomas A. J. (1971) Composition of lipid foams from swim-bladders of two deep ocean fish species. J. Lipid Res. 12, 331-335.

Rapport M. M. (1961) The $\alpha, \beta$-unsaturated ether (plas- malogen) content of the tissues of several mollusks. Biol. Bull. 121, 376-377.

Rapport M. M. and Alonzo N. J. 1960) The structure of plasmalogens. V. Lipids of marine invertebrates. J. biol. Chem. 235, 1953-1956.

Sampugna J., Johnson L., Bachman K. and Keeney $\mathbf{M}$. (1972) Lipids of Crassosirea virginica. I. Preliminary investigations of aldehyde and phosphorus containing lipids in oyster tissue. Lipids 7, 339-343.

Selivonchick D. P. and Roots B. I. (1976) Variation in myelin lipid composition induced by change in environmental temperature of goldfish (Carassius auratus). $J$. Therm. Biol. 1, 131-135.

Shinonura K., Hanjura S., Ki P. F. and Kishimoto Y. (1983) An unusual glycocerebroside in the crustacean nervous system. Science, Wash. 220, 1392-1393.

Snyder F. (1970) The biochemistry of lipids containing ether bonds. Prog. Chem. Fats 10, 364-365.

Snyder F. L. (1972) Ether Lipids: Chemistry and Biology. Academic Press, New York.

Stein R. A. and Slawson V. (1966) A model for fatty aldehyde dimethyl acetal gas-liquid chromatography. The conversion of octadecanal dimethyl acetal to methyl 1-octadecenyl ether. J. Chromatogr. 25, 202-212.

Thomas A. J. and Patton S. (1972) Phospholipids of fish gills. Lipids 7, 76-78.

Warren L., Buck C. A., Rabinowitz J. L. and Sherman I. W. (1979) Isolation and characterization of the erythrocyte surface membrane of the smooth dogfish, Mustelus canis. Comp. Biochem. Physiol. 62B, 474-479.

Williams J. N., Jr., Anderson C. E. and Jasik A. D. (1962) A sensitive and specific method for plasmalogens and other enol ethers. J. Lipid Res. 3, 378-381.

Wodtke E. (1981) Temperature adaptation of biological membranes. The effects of acclimation temperature on the unsaturation of the main neutral and charged phospholipids in mitochondrial membranes of the carp (Cyprinus carpio L.). Biochim. biophys. Acta 640, 698-709.

Zwingelstein G., Meister R, and Jouanneteau J. (1973) Métabolisme des phospholipides de la branchie et du foie d'anguille. Biochimica, Paris 55, 14951497.

Zwingelstein G., Meister R. and Brichon G. (1975) Métabolisme compareé des phospholipides des organs effecteurs de l'osmorégulation chez l'angulle européenne (Anguilla anguilla). Biochimica, Paris 57, 609-622.

Zwingelstein G., Portoukalian J., Rebel G. and Brichon G. (1980) Gill sulfolipids synthesis and seawater adaptation in eurhaline (sic) fish, Anguilla anguilla. Comp. Biochem. Physiol. 65B, 555-558. 